\title{
AN ANALYSIS OF FLOUTING MAXIM BY MAIN CHARACTER IN FREEDOM WRITERS MOVIE WRITTEN BY RICHARD LaGRAVANESE
}

\author{
Mariati $^{1}$, Asbah $^{2}$, Moh. Fauzi Bafadal ${ }^{3}$ \\ ${ }^{1,2,3}$ Pendidikan Bahasa Inggris, Universitas Muhammadiyah Mataram, mariati@gmail.com
}

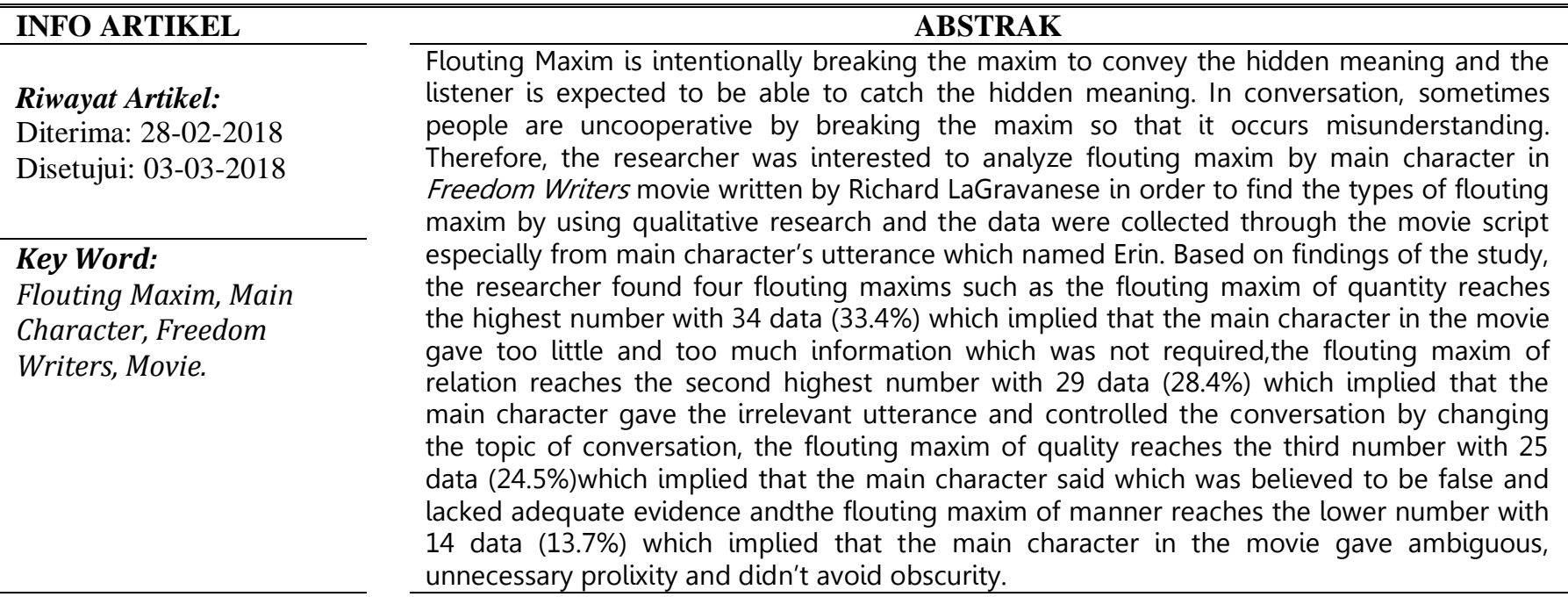

\section{A. BACKGROUND OF THE STUDY}

In the social life, human needs communication to connect with others by using the conversation. Through the conversation people can share anything with their society and friends. Conversation is one means by which people can coordinate the exchange of information (Bull and Aylett, 1998: 32). The information itself may be in the form of ideas or facts, and the particular characteristic of conversation is that it conveys social information. Conversation needs someone to be a speaker and a listener. They have to be cooperative and have contribution or message which can be understood by the listener in order that the communication is success.

To be successful in communicating through conversation, two or more people as the participants of a conversation should be able to be cooperative each other so there is no misunderstanding in the conversation. The speaker can lead the listener to gain the messages in the conversation clearly and the listener can understand the meaning even a hidden meaning in the speaker's utterance.

People have a good conversation if they fulfill the cooperative principle which is elaborated in four maxims: maxim of quantity, maxim of quality, maxim of relation, and maxim of manner (Grice in Yule, 1996: 37). However, sometimes people flout the maxims of conversation in his utterances because of some reasons and people are still assuming that they are in a cooperative conversation. This flouting act is called as flouting maxim.

Flouting maxim happens when the speaker or the listener gives an indirect utterance by flouting the maxims of conversation and yet they are still in a cooperative conversation. By flouting maxims, there are some hidden meanings that is tried to be conveyed by the speaker. That is when the speaker of a conversation intentionally breaks the maxims to convey hidden meanings. In his definition, Thomas (1995: 65) explains that flouting maxim means intentionally failing to follow the maxims of Cooperative Principle without any intention to deceive or make a misunderstanding. Everyone indeed has the possibility to flout the maxim of Cooperative Principle. Then, it can be assumed that whether the conversation is in the real life or even in a movie or in a novel that the script is made by people, flouting maxim can happen but movie is looking so real and it's different with the novel because we just read and imagine the narrations without seeing the real action of it. So, real action of the conversation can be showed through the movie and the conversation in the movie is not different in the real life.

A movie is a form of symbolic expressions of human being. It can be a reflection of humans' life since it is made based on social phenomena and cultural values. It is inspired by human, made by human, and played by human. The movie has the ability to record people and the events around them (Graham, 2005: 117). For another, Bordwell and Thompson (1997: 3) state that movies are equal with buildings, books, and symphonies. It differs from a novel which only provides narrations and conversations without performing it in reality. As a result, analyzing flouting maxim in a movie can represent an analysis of flouting maxim in human life. This study analyzed the movie which is title "An Analysis of Flouting Maxim in Freedom Writers Movie Written by Richard LaGravanese".

Freedom Writers is the movie which is interesting to be analyzed because in this movie there is a multicultural 
environment and there are many different racial groups in society so that their speaking style might be different. In this movie, people are mixed together in an environment and they are encouraged to accept the diversity to be united. This diversity will be possibility to happen flouting maxim because when they speak with another groups who have different cultural they sometimes have to break the rule of cooperative principle in the conversation by changing the topic and giving opinion from others perspectives, so that it will appear flouting maxim.

Related to the flouting maxim, there have been many researchers analyzing it in use. They are the first, the research from Anton Krismunandar (2013) entitled The Flouting of Cooperative Principle In Oprah Winfrey Show In Barack Obama Edition. It aims to describe the types of flouting maxim in the talk show. Besides, it aims to identify politeness principle as flouting maxim and explain the purposes of flouting maxim in the talk show.

The second, the research from Jihan Achyun Kusumaningrum (2012). She did a very different research of flouting maxim. She correlated it to the society in which gender. She analyzed flouting maxim as used by the male character in the movie Cinderella Man. The thesis is entitled A Socio-Pragmatic Analysis of the Flouting of Cooperative Principle Maxims done by the Male Main Character in Cinderella Man.

The third, the research from Lut Husaini Widi Hidayati (2015) entitled A Pragmatic Analysis Of Maxim Flouting Done The Main Characters In The Devil Wears Prada. The results of the research are all types of flouting maxim are found in the movie.

Therefore, based on the statement above the researcher proposed to analyze flouting maxim in a movie. This thesis title is "An Analysis of Flouting Maxim in Freedom Writers Movie." In this study addressed on: what types of maxim which were flouted by main character in Freedom Writers movie.

\section{B. RESEARCH METHOD}

In this research, the researcher used qualitative research. Qualitative research is a form of social inquiry focusing on the interpretation of experience and the world by people (Holloway, 1997: 1). Supporting this statement, states that qualitative research produces narrative or textual description of the phenomena under study (Vanderstoep and Johnston, 2009: 7). So, the researcher was be able to analyze the phenomenon of flouting maxim in detail. The researcher watched accurately "Freedom Writers" movie and analyzed the script to find out flouting maxim in the movie.

The data was taken from Freedom Writers movie script written by Richard LaGravenese in which the researcher became the primary instrument. Denscombe (2007: 274) states that qualitative data need to be prepared and organized before they can be analyzed. The procedures of collecting data were as follows:

1. The researcher downloaded Freedom Writers movie.

2. The researcher analyzed the movie based on the subtitle and red the transcript of the conversation to check whether which was spoken was the same as what was written.

3. The researcher collected the data from the script which reflected the phenomena of flouting maxim.
4. The researcher put all the data into a data sheet to (table 3.1)

\section{FINDING}

TABLE 1

AN ANALYSIS OF FLOUTING MAXIM IN FREEDOM WRITERS MOVIE WRITTEN BY RICHARD LaGRAVANESE.

\begin{tabular}{|c|l|c|l|c|}
\hline No & \multicolumn{1}{|c|}{ Flouting Maxim } & Occurrence & Percentage \\
\hline 1 & $\begin{array}{l}\text { Flouting Maxim of } \\
\text { Quantity }\end{array}$ & 34 & $33.4 \%$ & $81.3 \%$ \\
\hline 2 & $\begin{array}{l}\text { Flouting Maxim of } \\
\text { Relation }\end{array}$ & 29 & $28.4 \%$ & $3.0 \%$ \\
\hline 3 & $\begin{array}{l}\text { Flouting Maxim of } \\
\text { Quality }\end{array}$ & 25 & $24.5 \%$ & $2.4 \%$ \\
\hline 4 & Flouting Maxim of Manner & 14 & $13.7 \%$ \\
\hline \multicolumn{3}{|c|}{ TOTAL } & 102 & $100 \%$ \\
\hline
\end{tabular}

Based on the table above, it can be seen that the flouting maxim of quantity has the highest occurrence by main character in Freedom Writers movie written by Richard LaGravanese. There are 34 (33.4\%) utterances by main character in which the main character in the movie sometimes gave too little information and gave too much information which was not required.

The second highest occurrence is flouting maxim of relation, there are $29(28.4 \%)$ utterances by main character in the movie which is flouted since the main character said something irrelevant and sometimes changed the topic of conversation.

The third is flouting maxim of quality, there are 25 (24.5\%) utterances by main character in which the main character in the movie said what is believed to be false and lack of adequate evidence. Finally, the lowest occurrence is flouting maxim of manner, there are 14 (13.7\%) utterances by main character in which the main character gave an ambiguous, unnecessary prolixity and didn't avoid obscurity utterance.

\section{DISCUSSION}

\section{Flouting Maxim of Quantity}

Flouting maxim of Quantity happened when the main character gave too much information or too little information. It means that the main character didn't give the information as informative as it was required.

a. Margaret : Here's your coffee.

Erin : Thank you. I brought my lesson plans. I'd love it if you'd look them over.

It is called as flouting maxim of quantity because the main character added the information which was not required by saying "I brought my lesson plans. I'd love it if you'd look them over".Justby saying"Thank you", it was enough as the answer.

b. Margaret: It's too bad you weren't here even two years ago, you know. We used to have one of the highest scholastic records in the district, but since voluntary integration was suggested, we've lost over $75^{\circ}$ o $\underline{0}$ of our strongest students.

Erin : Well, actually, I chose Wilson because of the integration program. I think what's happening here is really exciting, don't 
you?My father was involved in the civil rights movement. And Iremember when I was watching the LA riots on TV, I was thinking of going to law school at the time. And I thought, "God, by the time "you're defending a kid in a courtroom, the battle's already lost."I think the real fighting should happen here in the classroom.

It is called as flouting maxim of quantity because the main character added the information which caused too much information by saying "I think what's happening here is really exciting, don't you?My father was involved in the civil rights movement. And I remember when I was watching the LA riots on TV, I was thinking of going to law school at the time. And I thought, "God, by the time "you're defending a kid in a courtroom, the battle's already lost."I think the real fighting should happen here in the classroom". Just by saying "Well, actually, I chose Wilson because of the integration program", it was enough as the answer.

c. Margaret : Well, that's a very well-thought-out phrase. Erin, I think you're a lovely, intelligent woman. But you're a first-time teacher.As head of this department,I have to be confident you're capable of dealing with what we have to face here.

Erin : I am. I know I have a lot to learn as a teacher, but I'm a really good student. I am, and I really want to be here.

It is called as flouting maxim of quantity because the main character added the information which caused too much information by saying "but I'm a really good student. I am, and I really want to be here".Just by saying "I am. I know I have a lot to learn as a teacher", it was enough as the answer.

d. Margaret : Those are lovely pearls.

Erin : Thank you. From my father.

It is called as flouting maxim of quantity because the main character added the information which caused too much information which was not required by saying "From my father".Just by saying "Thank you", it was enough as the answer.

e. Brian : You saw a little action today, I hear.

Erin : Yeah. It happened so fast.

It is called as flouting maxim of quantity because the main character added the information which caused too much information which was not required by saying "It happened so fast". Just by saying "Yeah", it was enough as the answer.

\section{Flouting Maxim of Relation}

a. Margaret: It's too bad you weren't here even two years ago, you know. We used to have one of the highest cholastic records in the district, but since voluntary integration was suggested, we've lost over $75^{\circ} / \stackrel{\circ}{\circ}$ of our strongest students.

Erin : Well, actually, I chose Wilson because of the integration program. I think what's happening here is really exciting, don't you? My father was involved in the civil rights movement. And I remember when I was watching the LA riots on $T V$, I was thinking of going to law school at the time. And I thought, "God, by the time "you're defending a kid in a courtroom, the battle's already lost."I think the real fighting should happen here in the classroom.

It is called as flouting maxim of relation because the main character gave the utterance which was not relation with the listener's utterance by saying "My father was involved in the civil rights movement. And I remember when I was watching the LA riots on TV, I was thinking of going to law school at the time. And I thought, "God, by the time "you're defending a kid in a courtroom, the battle's already lost."I think the real fighting should happen here in the classroom" while Margaret told of voluntary integration in the school but the main character gave the irrelevant information of voluntary integration after telling her amazement of integration program.

b. Steve : These gangs are criminals, not activists. You read the papers?

Erin : They said the same thing about the Black Panthers.

It is called as flouting maxim of relation because the main character gave the utterance which was not relation with the listener's utterance by saying "They said the same thing about the Black Panthers" while Steve asked whether she had read the papers of the gangs are criminals, not activists.

c. Erin : Can you hear what you're saying? How many times have I listened to you about walking civil rights marches?

It is called as flouting maxim of relation because the main character gave the utterance which was not relation with the listener's utterance by changing the topic and asking "How many times have I listened to you about walking civil rights marches?" while Steve said about her as a teacher and run a major corporation.

d. Steve : These gangs are criminals, not activists. You read the papers?

Erin : They said the same thing about the Black Panthers.

It is called as flouting maxim of relation because the main character gave the utterance which was not relation with the listener's utterance by saying "They said the same thing about the Black Panthers" while Steve asked whether she had read the papers of the gangs are criminals, not activists.

\section{Flouting Maxim of Quality}

When main character flouted a maxim of quality, the main character simply said something that didn't represent what she actually thought. That was saying what was believed to be false and saying that for which she lacked adequate evidence.

a. Margaret: It's too bad you weren't here even two years ago, you know. We used to have one of the highest scholastic records in the district, but since voluntary integration was suggested, we've lost over $75 \%$ of our strongest students.

Erin : Well, actually, I chose Wilson because of the integration program. I think what's happening here is really exciting, don't you? My father was involved in the civil rights movement. And I remember when I was watching the LA riots on TV, I was thinking of going to law school at the time. And I 
thought, "God, by the time "you're defending a kid in a courtroom, the battle's already lost." I think the real fighting should happen here in the classroom."

It is called as flouting maxim of quality because the main character gave the utterance in which she believed to be false by saying "I think what's happening here is really exciting, don't you?", while she knew that what happened in the school didn't really excited since it's always happened fighting. For another, she said "I think the real fighting should happen here in the classroom" while she knew that the real fighting should not happen in the classroom.

b. Margaret: Well, that's a very well-thought-out phrase. Erin, I think you're a lovely, intelligent woman. But you're a first-time teacher. As head of this department, I have to be confident you're capable of dealing with what we have to face here.

Erin : I am. I know I have a lot to learn as a teacher, but I'm a really good student. I am, and I really want to be here.

It is called as flouting maxim of quality because the main character gave the utterance in which she believed to be false by saying "but I'm a really good student" while she knew that she was not the student but she was the teacher.

c. Erin : Honey?

Scott : What?

Erin : Do I look like a teacher?

It is called as flouting maxim of quality because the main character gave the utterance in which she believed to be false while she knew that she was a teacher and it's not just her appearance that was like a teacher.

d. Brian : Well, don't be discouraged. You put your time in, in a few years, you'll be able to teach juniors. They're a pleasure. By then, most of your kids will be gone anyway.

Erin : What do you mean?

Brian : Well, eventually, they just stop coming.

Erin : Well, if I do my job, they might be lining up at the door.

It is called as flouting maxim of quality because the main character gave the utterance in which she believed to be false by saying "Well, if I do my job, they might be lining up at the door" while she knew that the students didn't obey the rule of class and the situation of class was so messy since they always fought.

e. Steve : With your brains, you could run a major corporation. Instead, I worry all night because you're a teacher at Attica.

Erin : Can you hear what you're saying? How many times have I listened to you about walking civil rights marches?

It is called as flouting maxim of quality because the main character gave the utterance in which she believed to be false by asking "Can you hear what you're saying?" while she knew that it's improbable the person can't hear what they say.

\section{Flouting Maxim of Manner}

Flouting maxim of manner happened when the main character gave unnecessary prolixity, disorderly, didn't avoid obscurity/of expression and ambiguity. It means that she didn't fulfill the result of the conversation. a. Scott : I'll lay odds your kids don't even know who Rap Brown or Eldridge Cleaver were. You're gonna waste your talent son people who don't give a damn about education. It breaks my heart. I tell you the truth.

Erin : Well...

I'm sorry. I can't help that.

It is called as flouting maxim of manner because the main character didn't avoid obscurity on her utterance by saying "I'm sorry. I can't help that".

b. Erin : Come in. There's room.

Scott : All right. Thank you.

Erin : I can't believe he brought up my salary. What's happened to him? He was like Atticus Finch to me when I was growing up, and now he's talking about salaries? I think he's playing too much golf. In fact, I think he needs an intervention. Why isn't being a teacher good enough for him?

It is called as flouting maxim of manner because the main character gave unnecessary prolixity and didn't avoid obscurity and didn't fulfill the result of the conversation by saying "I can't believe he brought up my salary. What's happened to him? He was like Atticus Finch to me when I was growing up, and now he's talking about salaries? I think he's playing too much golf. In fact, I think he needs an intervention. Why isn't being a teacher good enough for him?" while Scott just needed the appropriate answer of word "Thank you".

c. Scott : He just doesn't think I'm good enough for you, which is fine. That's what fathers do. I'm sure I'll be that way someday. Look, just, you know, stop worrying about being his perfect daughter. You don't live in his house, you live in ours. Or until we find one.

Erin : Or untilyou build us one.

It is called as flouting maxim of manner because the main character didn't avoid obscurity on her utterance by saying "Or until you build us one".

d. Erin : Or until you build us one.

Scott : Yeah.

Erin : With extra sinks.

It is called as flouting maxim of manner because the main character didn't avoid obscurity on her utterance by saying "With extra sinks".

e. Scott : You're gonna sell bras at a department store?

Erin : Just part-time. I'm having a little trouble getting books and things for the kids. So, a little extra money will give me a little more freedom to do what I want.

It is called as flouting maxim of manner because the main character didn't avoid obscurity on her utterance by saying "Just part-time. I'm having a little trouble getting books and things for the kids. So, a little extra money will give me a little more freedom to do what I want".

\section{E. CONCLUSSION AND SUGGESTION}

\section{Conclussion}

Based on the research findings and discussion in chapter four, there are the conclusions which can be described as follows:

Based on the finding in chapter 4 , it can be seen that the characters in Freedom Writers often flouted the 
maxims of cooperative principle. They are four flouting maxims of cooperative principle, i.e. flouting of maxim quantity, flouting of maxim quality, flouting of maxim relation, and flouting of maxim manner. The flouting maxim of quantity reaches the highest number with 34 data (34\%). It implies that the main character in the movie gave too little and too much information which is not required. The flouting maxim of quality and the flouting maxim of relation reach the same number namely the flouting maxim of quality is with 24 data (24\%). It implies that the main character said which was believed to be false and lacked adequate evidence while the flouting maxim of relation is with 30 data $(30 \%)$. It implies that the main character gave the irrelevant statement and controlled the conversation by changing the topic of conversation. The flouting maxim of manner reaches the lower number with 12 data (12\%). It implies that the main character in the movie gave ambiguous, prolix and unclear information. It indicates that flouting of manner does not really contribute in this analysis since most of the characters always tried to give truth and believable information.

\section{Suggestion}

It is essential to study flouting maxim of Cooperative Principle because people will know that the speaker's intention is sometimes different from what is stated. By understanding flouting maxim, they are able to get the inference of what are being meaning of conversation so that they can converse well and avoid misunderstanding.

In study process, understanding and analyzing flouting maxim of Cooperative Principle can be done through watching movies or reading novels. It will make the students understand clearly about flouting maxim when they analyze it than they only get the materials theoretically from their lecturers.

By learning and understanding of flouting maxim, people will be more understand in their communication process in daily life because they have the knowledge and understanding of what the hidden meaning in what people said.

\section{ACKNOWLEDGEMENT}

The researcher would like to thanks to Mr. Asbah, M.Hum as first consultant and Mr. Moh. Fauzi Bafadal, M. $\mathrm{Pd}$ as second consultant who always give guidance, advising, and motivation to the researcher until this research has done well. Then, the researcher would like to say thanks for Hidayati, M.Hum and Humaira, M. Pd as my examiners who had given some correction and revision in researcher thesis.

\section{REFERENCES}

[1] Arikunto, S, Prosedur Penelitian Suatu Pendekatan Praktik, PT. Rineka Cipta, Jakarta, 2013.

[2] Humaira., "Different Interpretation of Ambiguities Sentences (A Study of Class C The Second Semester Postgraduate Students Majoring English of State University of Semarang), September, 2015.

[3] Hidayati, Asbah, Agung A, The Semantics Study of English Slang used in the Column Cosmo Megazine. September, 2013

[4] Hidayati, Rusnaini. The Use of Semantic Mapping to Increase Students Vocabulary at The Second Grade students of SMPN 9 Mataram in Academic Year 2014/2015. September 2016

[5] Hijril, ismail. Improving Students Speaking Skill Through Conversation. April,2014

\section{The Researcher Profile}

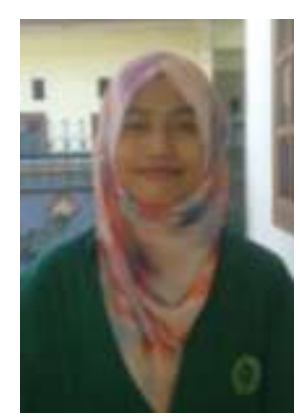

The researcher is "Mariati" who was born on Naru, 20 June 1994. The researcher is the fifth children of five people. Elementary School was began from SDN Inpres Dea on years 20012006. After that, was continued at SMPN 1 Sape of years 2007-2009 and the last at SMA PGRI Sape 1 of years 2010-2012. Then, the researcher was continued at Muhammadiyah University of Mataram in English Education Program FKIP UM Mataram on 2013. Suggestion and criticism or the improvement of this research that has connection with my journal you can send it through via e-mail in : mariati@gmail.com. 